\title{
Fire-Sale FDI? \\ The Impact of Financial Crises on Foreign Direct Investment
}

\author{
Olga Bogach* \& Ilan Noy \\ Department of Economics \\ University of Hawai'i at Manoa
}

January 13, 2012

\begin{abstract}
In this paper, we analyze the evolution of foreign direct investment (FDI) inflows to developing and emerging countries around financial crises. We empirically and thoroughly examine the Fire-Sale FDI hypothesis and describe the pattern of FDI inflows surrounding financial crises. We also add a more granular detail about the types of financial crises and their potentially differential effects on FDI. We distinguish between Mergers and Acquisitions (M\&A) and Greenfield investment, as well as between different motivations for FDI-horizontal (tariff jumping) and vertical (integrating production stages). We find that financial crises have a strong negative effect on inward FDI in our sample. Crises are also shown to reduce the value of horizontal and vertical FDI. We do not find empirical evidence of Fire-Sale FDI. On the contrary, financial crises are shown to affect FDI flows and M\&A activity adversely.
\end{abstract}

JEL Classification: F21, F23, F29, G01, G34

Keywords: International investment, Foreign direct investment (FDI), Financial crises, Mergers and Acquisitions, Multinational firms

* (corresponding author) Department of Economics, University of Hawai'i at Mānoa, Saunders Hall 540, Honolulu, HI 96822, Email: omoulton@hawaii.edu. 


\section{Introduction}

Paul Krugman, in a much cited paper on the Asian 1997-8 crisis, starts by arguing that: "hard statistical evidence of a surge in FDI into Asia was not yet available" but that anecdotal evidence strongly suggests an inflow of FDI in the post-crisis period (Krugman, 2000 , p. 44). Yet, the idea that financial crises are sometime also accompanied by FireSale FDI (the title of Krugman's paper) caught on. Krugman concludes his paper, written sometime in 1998, noting that: "What we need-surprise-is more research." We believe this is still the case today. There is very little research that attempts to systematically document the evolution of foreign direct investment around financial crises. ${ }^{1}$ This is what we do in this paper.

The importance of foreign direct investment (FDI) to the global economy in the last few decades is quite obvious, with increasing volumes of FDI flowing between, into and more recently from the developing countries and emerging markets (see Table 1). In 2010, for the first time, developing and transition economies together attracted more than half of global FDI flows (UNCTAD World Investment Report 2010). Even though the theoretical literature in economics has identified several channels through which FDI inflows are predicted to benefit the receiving economy, the empirical literature has lagged behind and has had more trouble identifying these advantages in practice. Notwithstanding these uncertain empirical observations, most countries continue to rigorously pursue policies aimed at encouraging more FDI inflows.

\footnotetext{
${ }^{1}$ Notable exceptions are Aguiar and Gopinath (2005) measurement of the increase in foreign firms' M\&A activity during the Asian crisis, and Acharya et al. (2011) who provide a theoretical background to the empricial insights provided by the former paper about the effect of the Asian currency crises. UNCTAD (2000) describes some of the underlying data.
} 
While much of the literature on FDI focuses on the impact of FDI on technological transfer, increasing productivity and production, one frequently identified advantage of FDI flows is its perceived stability relative to other types of capital flows. Empirical research shows that FDI flows tend to be much less volatile than equity flows or bank lending, for example (Osei et al., 2002). A related and intriguing hypothesis is that, unlike other types of capital flows, FDI tends to 'lean against the wind' and inflows may increase during a financial crisis, when all other types of capital are fleeing the scene.

In this paper, we analyze the pattern of FDI inflows to emerging and developing countries focusing on the impact of financial crises on these flows. We contribute in several ways. Our paper is the first to empirically and thoroughly examine the Fire-Sale FDI hypothesis and describe the pattern of FDI inflows surrounding financial crises. We further contribute by adding more granular detail about the types of financial crises and their potentially differential effects on FDI-this was after all the subject of Krugman's (2000) paper, in which he analyzed the predictions of various theoretical crisis models on the viability of FDI. We also expect differing types of FDI to react differently to financial turmoil, and we therefore distinguish between different types of FDI-i.e., Mergers and Acquisitions ( $M \& A$ ) and Greenfield investments-and between different motivations for FDI-horizontal (tariff jumping) and vertical (integrating production stages).

Below we describe the hypotheses we investigate in some detail, and within the context of the few papers that had looked at these questions. Section 3 then presents 
our data on the various types of FDI and the typology of financial crises we use, the empirical model and the estimation methodology. Section 4 analyzes our results and discusses these results within the context of the ongoing global crisis that started in September 2008.

\section{Different Crises, Different FDI, and Different Impacts}

\subsection{A Typology of Financial Crises and their Impacts}

Since the re-emergence of financial turmoil during the 1970s, the economic literature on the topic has developed rapidly. The literature initially focused on currency crises, the mainstay of the 1970 s turmoil, but later on also investigated banking crises, periods of high or hyper-inflation, and the debt crises of the 1980s, and finally in the 1990s, crises of capital flow reversals (the so-called Sudden Stops). However, since FDI emerged on the international scene in significant amount only in the 1980 s, we use data for 1987-2009, and examine all these types of financial crises.

The two early generations of the theoretical currency crisis literature emphasized different fundamental reasons for a crisis. The first-generation models emphasized fiscal sustainability and the inevitability of crisis given fiscal policy choices (Krugman, 1979, Flood and Garber, 1984 and Burnside et al., 2001). In these models, the exchange rate peg is dropped during the crisis and the exchange rate continues to depreciate so long as the government continues to monetize its deficit. There is no real exchange rate change and therefore incentives for embarking on FDI projects do not change. The second generation of this literature, however, emphasizes multiple 
equilibria, and implies that crisis equilibrium may entail new opportunities for foreign direct investment since the real exchange rate depreciation is not necessarily related to a cyclical deterioration of the economy but potentially to shifts in expectations (e.g., Obstfeld, 1994, Drazen and Masson, 1994, Chamley, 2003).

The decade following the Asian crisis of 1997-8 yielded a new crop of crisis modeling, with many models emphasizing the importance of moral hazard created by government guarantees (Corsetti et al., 1999 and Dooley, 2000). These models largely imply a collapse of an over-investment bubble, and therefore very weak incentives for FDI in the crisis aftermath. A separate group of crisis models emphasize Diamond-Dybvig type banking runs and the breakdown in financial intermediation (e.g., Chang and Velasco, 2001, Uhlig, 2010); these, like the second generation currency crisis literature, may present opportunities for FDI.

A different crop of theory papers emphasize the reversals of capital flows ('Sudden Stops' as coined by Calvo, 1998) and their impact on the domestic economy. Sudden stops have been found to lead to dramatic if temporary output contractions especially if they involve a Fisherian debt deflation cycle (e.g., Hutchison and Noy, 2006, Mendoza, 2010). In these cases, the deep recession will likely weaken the incentives of foreign investors to enter the domestic market, and therefore these crises are predicted to reduce horizontal FDI. The possible impact of debt crises and the accompanying debt defaults are more difficult to characterize, since the impact of debt defaults is not well established (e.g., Rose, 2005). Even less well known are the differences in the macroeconomic consequences of domestic versus foreign debt defaults/crises. 
We follow Krugman in arguing that in order to formulate a clear hypothesis on the impact of financial crises on FDI, one needs to understand the fundamental mechanisms that cause and shape the evolution of financial crises in the first place. In empirical terms, this means we need to control for the type of crisis a country experiences when evaluating the crisis impact on FDI. We are the first paper to have attempted to do that.

\subsection{Types of FDI and their Vulnerability to Financial Crises}

As we have already observed, financial crises that are caused by different phenomena are predicted to have different consequences for the domestic economy. In particular, some will lead to domestic contractions (maybe even deep recessions), while others may lead to an expansionary depreciation. Equally, a financial/monetary crisis may not have much impact on the real economy and therefore fail to affect the incentives faced by international investors. These different outcomes will potentially also impact distinctively the differing forms of direct investment; with the relative attractiveness of investing in existing infrastructure, through $M \& A$, relative to constructing new production facilities (greenfield investment) may be shifting as well.

These distinctions also relate to the different time horizons that $M \& A$ and greenfield investment entail. M\&A can typically be implemented much more quickly, since it does not entail a time-consuming permitting stage that typically accompanies new projects (especially in emerging markets). If a crisis is predicted to be short-lived, 
and especially if a real depreciation is perceived to be temporary, an M\&A boom, as compared to an increase in greenfield investment, is likely to be observed.

Following the FDI literature, we also distinguish between horizontal and vertical FDI (Aizenman and Marion, 2004). We examine the hypothesis that the differences between the motivations for FDI also matter for their vulnerability to financial crises. Horizontal FDI targets the domestic market (or maybe neighboring markets), so that a financial crisis that entails a real contraction will adversely affect horizontal FDI. Vertical FDI, on the other hand, is mostly concerned with production costs (and production quality); in this case a real depreciation may be very beneficial for integrating production networks vertically by reducing the costs associated with this process, whatever the state of the domestic/host economy is and will likely remain. Vertical FDI is also more closely associated with increased trade, and therefore can also be affected by the impacts of financial crises on trade relations (Aizenman and Noy, 2006 and 2009).

Empirically, we employ a country-panel regression approach using Arellano-Bond $(A B) G M M$ estimation. $A B G M M$ is by now the standard in the international macro literature that uses country time series panels and we therefore do not include a detailed discussion of the estimation algorithm and its justification. It is worth noting that the algorithm enables us to disregard the time-invariant institutional, legal and cultural environment in which FDI projects are implemented and which may have an important impact on FDI inflows, and also deal with some types of endogeneity (though at least reverse causality is not a major concern in this case as few commentators view FDI as potentially destabilizing for the financial system). 


\subsection{Relevant Previous Empirical Work on FDI}

Beyond the papers that focus on the Fire-Sale FDI of the Asian Crisis of 19971998 (Aguiar and Gopinath (2005) and Acharya et al. (2011)), the only other paper that looks at a similar question is Soliman (2005) who analyzes the impact of currency crises on outgoing U.S. FDI and finds some evidence of a Fire-Sale (or at least an increase in FDI following the crisis). Several other papers that directly relate to our research program are worth mentioning.

Alfaro et al. (2004) focus on the ways in which the growth effects of FDI depend on the strength of the domestic financial markets of the host country. The implication of their findings appears to be that a country with post-crisis weakened financial sector will likely gain less from FDI (FDI will be less productive) and therefore will experience reduced inflows. Dell'Ariccia et al. (2008) present related evidence on the heighted vulnerability to financial dis-intermediation of sectors that rely on foreign investment. Several papers have also investigated the response of foreign multinationals to a sharp depreciation of the currency in the host economy, without directly examining FDI. Using U.S. multinational data, for example, Desai et al. (2008) find that foreign firms increase their own investment, following a large depreciation, relative to domestic firms.

\section{Data Sources, Descriptive Statistics and Estimation}

Blonigen and Wang (2005) and Noy and Vu (2007) argue that mixing wealthy and poor countries is inappropriate in empirical FDI studies. They note that the factors that 
affect FDI inflows are different across income groups. We therefore focus only on developing/emerging markets. We leave a similar investigation for developed countries for future work. We also exclude OPEC member countries as their FDI is heavily concentrated in natural resources. Our sample therefore contains 40 emerging/developing countries (a detailed list is included in the appendix Table A). Our data cover yearly observations for the period of 1987-2009. Appendix Table C contains a full list of data sources used in our analysis.

\section{1. $M \& A$, greenfield, horizontal and vertical FDI}

Only a few papers have distinguished between different types of FDI and treated them as separate types of capital flows. A recent example, Wang and Wong (2009) investigate the growth impact of $M \& A$ and Greenfield foreign direct investment separately, as does an earlier paper by Calderón et al. (2004). More directly relevant to our work, Alquist et al. (2009) investigate whether M\&A projects that were implemented in a post-crisis environment (i.e., Fire-Sale M\&A) fail more often that noncrisis-induced M\&A.

Given a lack of common source for FDI data, we collected data on four different FDI measures that have been typically used in previous studies: FDI flows, FDI stocks, Mergers and Acquisitions (M\&A), and foreign affiliate sales.

Our source of cross-country FDI flows, stocks, and cross-border mergers and acquisitions (M\&A) is UNCTAD's FDI database, compiled by Thomson Financial. UNCTAD classifies foreign direct investment as an "investment involving a long-term relationship 
and reflecting a lasting interest and control by a resident entity in one economy of an enterprise resident in a different economy" (UNCTAD, 2009). M\&A are defined as the mergers with, or acquisitions of, domestic firms by a single foreign investor with more than ten percent equity capital. Data on cross border M\&A have been used in such studies as Rossi and Volpin (2004) and Head and Reis (2008). One limitation of this dataset is a substantial amount of missing values, and possibility of significant underreporting, since many of the transactions are between private firms.

Following Calderon et al. (2004) and Wang and Wong (2009), we construct a measure of greenfield FDI by subtracting cross-border M\&As from FDI inflows. While this proxy is not ideal, UNCTAD documents that FDI can be considered approximately as the sum of greenfield investment and M\&As (UNCTAD, 2000, p.114-119)2.

To distinguish between horizontal and vertical FDI, we use the destination market for the sales of U.S. multinationals since 1987 (data from the U.S. Bureau of Economic Analysis ). Following Hanson et al. (2002) and Aizenman and Marion (2004), we measure vertical investment as affiliate sales either back to the U.S. or to other foreign countries. Horizontal investment is defined by affiliate sales in the local market where the affiliate resides. The assumption is that the latter are sales of final goods, while the former represent intermediate goods requiring further processing in the parent country or a third county. This is the best available metric to distinguish between horizontal and vertical FDI. Moreover, several studies (e.g., Carr, et al., 2001, and

\footnotetext{
${ }^{2}$ Given the lack of existing greenfield investment data, this measure is the most natural alternative proxy. However, since FDI data are reported on a balance-of-payment basis, where inward FDI in a host country is measured as the aggregation of greenfield investment, M\&A sales, re-investments, and disinvestments undertaken by MNCs, this proxy does not perfectly reflect the actual value of greenfield investment.
} 
Bergstrand and Effer, 2007) have stressed the use of affiliate sales as the most appropriate measure of actual multinational firm activity in a host country.

Table 1 reports FDI statistics for our sample of 44 developing countries by region, decade and type of FDI. We note that well known dramatic increase in FDI volumes over the last 30 years that is observable for all regions and all types of FDI. We also observe that comparatively, FDI in Asia is more vertical, and less M\&A compared to Latin America, the other region that receives a lot of FDI.

[Insert Table 1 Here]

\subsection{Typology of crises and data sources}

The literature on financial crises is quite large, but only in the last few years a typology of crises has become used more often, especially since the publication of the comprehensive examination of the historical record provided by Reinhart and Rogoff (2009). We follow Reinhart and Rogoff (henceforth R\&R) in identifying banking, currency, debt (external and domestic), stock market, and inflation crises. We also distinguish severe crises: systemic banking crises (as identified by bank runs that lead to the closure, merging, or takeover by the public sector of one or more financial institutions), and hyperinflation crises (identified as an annual inflation rate of $500 \%$ or higher).

$R \& R^{\prime} s$ comprehensive data set on financial crises provides data on the dating of various types of crises in seventy countries over the period 1970-2010. It builds heavily on the work of earlier scholars, but also employs a considerable amount of new material 
from diverse primary and secondary sources. We focus on the period of 1987-2009

when FDI became prevalent in developing countries.

To identify systemic banking crises, we use a database developed by Leaven and Valencia (2010). The database builds on the Caprio, et al. (2005) banking crisis database and covers worldwide systemic banking crises for the period of 1970-2007. We provide detailed definitions of the typology of crises in the Appendix Table B.

Table 2 presents a summary of our data on crisis types in our sample. It reports the number of distinct crises episodes as well as the total number of years in crises by crisis type and by decade.

[Insert Table 2 Here]

As can be seen from Table 2, developing countries have been prone to financial crises in the last two decades. In the period of 1987-2009, developing countries experienced 68 distinct banking crises episodes, 42 of which constituted systemic banking crises. Currency crises occurred in developing countries 118 times, adding up to a total of 326 years of currency crises, or an average of 8 years per country. Inflation crises were less prevalent - 54 distinct episodes with 10 hyperinflation episodes. Stock markets crashed a total of 90 times, and there were 54 (17) episodes of external (domestic) debt crises. There is no apparent increasing time trend in the frequency of crises among developing/emerging countries, in spite of the recent global turmoil.

\subsection{Control variables}

Our main concern in the choice of additional variables to include in our estimation is to prevent any omitted variables bias from affecting the estimates we 
obtain for our RHS variables of interest (the financial crisis indicators). Given this concern, we choose to err on the side of caution and include an extensive list of controls. Blonigen and Piger (2011) conclude, using Bayesian averaging technique, that a fairly extensive list of controls should be included in FDI regressions, though they also point to a few that are probably not robustly associated with FDI.

Adhering to their findings, we control for broad macroeconomic conditions, political, socio-economic, and business environment in the host country by using a set of indicators on corruption, government stability, and investment climate from the Freedom House and International Country Risk Guide - Political Risk Service (ICRG-PRS) databases. We also include measures from the World Bank's World Development Indicators (WDI) on relative factor endowments, communications infrastructure, and trade costs. Finally, we control for geographic spatial issues and possible agglomeration effects by using the data from Penn World Tables and CEPII Gravity data set (Head et al., 2010). Additional data sources for our control variables are Barro and Lee (education data set) and Li et al. (2011) dataset on per capita real capital.

The list of all controls used in our analyses and the corresponding data sources is included in the appendix Table C. For readability, we do not include coefficients for these controls in the reported regressions in tables 3-8; complete results are available upon request.

\subsection{Estimation Methodology}

We estimate the following equation: 
$F D I_{i t}^{T}=\beta_{1}+\beta_{2} C R I S_{i t}^{P}+\beta_{3} X_{i t}+\varepsilon_{i t}$

Where $F D I_{i t}^{T}$ is the measure of FDI inflows for country $i$ in year $t$, and of type $T$ (M\&A, greenfield, horizontal, vertical), $C R I S_{i t}^{P}$ is the binary crisis indicator for crisis type $P$, and $X_{i t}$ is a vector of control variables as described the previous section. We use panel Arellano-Bond GMM estimation (with STATA) instead of relying on the cross-sectional datasets that are sometimes used in the FDI literature. Using panel estimation highlights several advantages over a conventional cross-section. Panel estimation methods offer us a way to control for unobservable time-invariant effects and hence give more reliable estimates, while the AB-GMM estimation algorithm allows us to control for potential endogeneity of some of the control variables within the context of a dynamic panel.

We treat the crisis variable as predetermined, assuming that the current period error term is uncorrelated with current and lagged crises, but may be correlated with the future crises. It is a weaker restriction than strict exogeneity, which requires the variable to be uncorrelated with past, present, and future shocks. We also follow the standard practice of reporting the one-step estimates as Arellano and Bond (1991) show that the two-step procedure has poor finite sample properties.

A final issue that we should address is that of using too many instruments. When using estimators of this type, the number of instruments will increase at a rate that is quadratic in T. As discussed by Roodman (2009), the fundamental issue here is that when there are too many instruments relative to the sample size, the $R^{2}$ on the first stage will approach unity and so the second stage estimator will be almost equivalent to 
OLS. To address this problem, we follow the literature and limit the maximum number of lags that can be used as instruments at one.

\section{Results}

Tables 3-8 report the results of our empirical analysis. For each measure of FDI activity, we use ten different specifications: Regressions (1) - (8) include each crisis separately, in (9) we include all crises jointly, and in (10) we only include severe crisis episodes (severe banking crises and hyperinflation). Coefficients for our other control variables are often significant with the expected sign. FDI is positively related to host country's level of government stability, GDP per capita, gross fixed capital formation, and socioeconomic conditions. Education level in host country has a positive effect on greenfield and horizontal investment, but a strong negative effect on total FDI flows and vertical FDI in particular, suggesting that the majority of FDI is attracted to cheap labor in host developing countries. Surprisingly, greenfield FDI and horizontal FDI are also positively affected by corruption and negatively by the quality of institutions.

Table 3 reports the estimates for determinants of FDI flows. Coefficients for banking crisis, inflation crisis, hyperinflation crisis, and external debt crisis are all negative and statistically significant. Banking crises are shown to reduce FDI by \$US 3.4 billion ( $p=0.00$ ), while inflation and hyperinflation crises lead to a decrease in FDI flows by 2.9 billion $(p=.00)$, and 19.7 billion $(p=.00)$ dollars respectively. An external debt crisis in a given year is shown to decrease FDI flows by \$US 5.5 billion dollars $(p=.00)$. Coefficients on stock market crash, currency, and domestic debt crises are insignificant. 
[Insert Table 3 here]

Table 4 reports the estimates for determinants of FDI stocks. Coefficients for banking crisis, inflation crisis, and external debt crisis are all negative and statistically significant, shown to reduce FDI by \$US 127.1 billion, 136.0 billion $(p=.04)$, and 152.2 billion ( $p=.07$ ) dollars respectively. When only the severe crises are included, a hyperinflation crisis in a given year is shown to decrease FDI stocks by \$US 1,284.4 billion dollars $(p=.00)$. Coefficients on stock market crash, currency, and domestic debt crises are insignificant.

[Insert Table 4 here]

We then distinguish between the different motivations for FDI and examine the effects of the crises on vertical and horizontal FDI separately. We observe in Table 5 that an inflation crisis (and particularly a hyperinflation crisis) has a strong negative and significant effect on vertical FDI in our sample. An inflation crisis in a given year is shown to decrease vertical FDI by \$US 29.8 billion $(p=.01)$ Hyperinflation exaggerates this effect tenfold to \$US 299.3 billion $(p=.00)$. External debt crises are also shown to reduce the value of vertical FDI by \$US 32.9 billion $(p=.00)$. The effects of the other types of crises on vertical FDI are shown to be insignificant.

[Insert Table 5 here]

Horizontal FDI targets the domestic market, so we expect that a financial crisis that entails a real contraction will adversely affect horizontal FDI. Indeed, we observe (Table 5) the same types of crises that affect vertical FDI, have a strong negative effect on horizontal investment. We find that an inflation crisis and hyperinflation crisis reduce 
the value of horizontal FDI by \$US $65.3(p=.02)$ and $\$$ US $580.5(p=.00)$ billion respectively in a given year. External debt crisis also negatively impacts horizontal FDI, reducing its value by $\$$ US 86.7 billion dollars $(p=.00)$. We also find that a systemic banking crises increases the value of horizontal FDI by \$US 34.6 billion ( $p=.07)$.

[Insert Table 6 here]

Table 7 reports our results on M\&A investment. We find that, contrary to the fire-sale FDI hypothesis, financial crises have a significant adverse effect on the value of M\&A. In particular, banking crises are shown to reduce M\&A investment by \$US 1.4 billion ( $p=.02$ ). Both domestic and external debt crises also affect $M \& A$ investment adversely, reducing its value by \$US $2.4(p=.04)$ and \$US $1.6(p=.05)$ billion dollars respectively. This leads us to reject the fire-sale FDI hypothesis, and we discuss the possible explanation behind this in the concluding section of the paper. Lastly, we examine the effects of FDI on greenfield investment and find no significant effect.

$$
\text { [Insert Table } 7 \text { here] }
$$

To ensure the robustness of our results, we replicate our analysis using nominal and logged values of FDI as dependent variable, and including additional lags of financial crises. The signs and significance of our coefficients of interest remain largely unchanged

\section{Conclusions}

We find that financial crises have an adverse effect on FDI in our sample of developing and emerging countries. In particular, banking crises, inflation crises, 
hyperinflation crises, and external debt crises lead to a significant decline in FDI inflows. Crises are also shown to reduce the value of vertical FDI, horizontal investment, and M\&A. In general, we do not find empirical evidence of Fire-Sale FDI in our sample of developing countries.

While these results may seem expected, they directly contradict Krugman's Firesale FDI hypothesis. Two possible explanations are rendered below. First, Krugman was not wrong, but rather Asia was unique and the reasons for the Asian crisis different. While Krugman focused on the Asian financial crises, our sample is broader both in the coverage of countries and years. We find no evidence of fire-sale FDI following an average financial crisis in developing countries. Secondly, as is the case with any macroeconomic data, there are questions about the quality of FDI data (particularly, M\&A data) and it may be that the data are simply not good enough to identify the pattern.

The topic of financial crises and FDI is an important and timely one today given the rapidly spreading global financial turmoil and particularly the debt crises in Europe. The findings of the paper are relevant not only because they evaluate the effects of crises on FDI, but because they inform us about the types of crises that these countries are experiencing. Just as Krugman concluded, observing or not observing fire-sale FDI lends support to either the fundamental explanation or the panic view behind the cause of the crisis. With regards to FDI, the findings are relevant as FDI is becoming increasingly important as a form of capital flows, and changes in the valuation of FDI projects also leads to significant international transfers of wealth. 
Our results find support in the FDI turnaround that is apparent in the immediate aftermath of the $2008-2010$ economic downturn, by far the most global financial crisis since the great depression (Bordo and Landon-Lane, 2010). While the long-run effects of this global crisis still remain to be seen, the current global downturn has been accompanied by a precipitous decline in FDI flows worldwide of $40 \%$ between the peak in 2007 and the trough in 2009 (UNCTAD, 2011).

The recent crisis, of course, was global, so credit contracted everywhere; that is not the usual turn of events surrounding a financial crisis that is limited to a specific country and/or region. Yet, even in these cases, we observe large declines in FDI inflows of all types. These findings do not contradict the consensus that FDI is preferable to 'hot money' during times of financial turmoil. The FDI reversals that we record are still probably much smaller than the reversals associated with other types of financial flows (especially short-term lending and equity). 


\section{References}

Acharya, Viral, Hyun-Song Shin and Tanju Yorulmazer. (2011) “Fire-sale FDI," Mimeo.

Aguiar, Mark, and Gita Gopinath. (2005) "Fire-Sale FDI and Liquidity Crises," Review of Economics and Statistics, 87(3).

Aizenman, Joshua, and Nancy Marion (2004). "The Merits of Horizontal Versus Vertical FDI in the Presence of Uncertainty, "Journal of International Economics 62, 125- 148.

Aizenman, Joshua and Ilan Noy. (2006) “FDI and Trade: Two Way Linkages?” Quarterly Review of Economics and Finance, 46(3), 317-337.

Aizenman, Joshua and Ilan Noy. (2009) "Endogenous Financial and Trade Openness," Review of Development Economics, 13(2), 175-189.

Alfaro, L., Chanda, A., Kalemli-Ozcan, S. Sayek, S. (2004) “FDI and Economic Growth: The Role of Local Financial Markets," Journal of International Economics 64, 89-112.

Arellano, M. and S. Bond (1991) "Some Tests of Specification for Panel Data: Monte Carlo Evidence and an Application to Employment Equations," Review of Economic Studies, 58(2), 277-297

Barro, R. and J. Lee. (2010) "A New Data Set of Educational Attainment in the World, 1950-2010," NBER Working Paper No. 15902.

Bergstrand, J and Egger, P. (2007) “A Knowledge-and-Physical-Capital Model of International Trade Flows, Foreign Direct Investment, and Multinational Enterprises," Journal of International Economics, 73(2): 278-308.

Blonigen, Bruce A., and Jeremy Piger. (2011) “Determinants of Foreign Direct Investment," NBER working paper 16704.

Blonigen, B., Wang, M. (2005). "Inappropriate Pooling of Wealthy and Poor Countries in Empirical FDI Studies,” In: Moran, T.H., Graham, E.M., Blomström, M. (Eds.), Does Foreign Direct Investment Promote Development? Institute of International Economics Press: Washington DC.

Bordo, Michael D. and John S. Landon-Lane. (2010) "The Global Financial Crisis of 200708: Is it Unprecedented?" NBER Working Paper No. 16589.

Burnside, Craig, Martin Eichenbaum and Sergio Rebelo. (2001) "Prospective Deficits and the Asian Currency Crisis," Journal of Political Economy 109(6). 
Calderón, César, Norman Loayza, and Luis Servén. (2004) "Greenfield Foreign Direct Investment and Mergers and Acquisitions: Feedback and Macroeconomic Effects," World Bank Policy Research Working Paper 3192.

Calderón, César and Tatiana Didier. (2009) "Will FDI be Resilient in this Crisis?" World Bank Office of the Chief Regional Economist - LAC.

Caprio, G., Klingebiel, D., and Laeven, L., and G. Noguerra. (2005) "Appendix: Banking Crises Database, " in Patric Honohan and Luc Laeven (eds.), Systemic Financial Crises: Containment and Resolution. Cambridge, U.K: Cambridge University Press.

Carkovic, M., Levine, R. (2005) "Does Foreign Direct Investment Accelerate Economic Growth?" In: Moran, T.H., Graham, E.M., Blomström, M. (Eds.), Does Foreign Direct Investment Promote Development? Institute of International Economics Press: Washington DC.

Carr, D., Markusen, J., Maskus, K. (2001) "Estimating the Knowledge-Capital Model of the Multinational Enterprise," American Economic Review, Vol. 91(3):693-708.

Chamley, Christophe. (2003) Dynamic Speculative Attacks. American Economic Review.

Chang, Roberto and Andres Velasco. (2001) "A Model of Financial Crises in Emerging Markets." Quarterly Journal of Economics, 489-518.

Corsetti, Giancarlo, Paolo Pesenti, and Nouriel Roubini. (1999) "Paper Tigers? A Model of the Asian Crisis," European Economic Review, 43, 1211-1236.

Dell'Ariccia, Giovanni, Enrica Detragiache, and Raghuram Rajan. (2008) "The Real Effect of Banking Crises," Journal of Financial Intermediation 17, 89-112.

Dooley, Michael. (2000) "A Model of Crises in Emerging Markets," Economic Journal 110, 256-272.

Diamond, Douglas and Phillip Dybvig. (1983) “Bank Runs, Deposit Insurance, and Liquidity," Journal of Political Economy, 91(3), 401-419.

Desai, Mihir, C. Fritz Foley, and Kristin Forbes. (2008) "Financial Constraints and Growth: Multinational and Local Firm Responses to Currency Crises," Review of Financial Studies 21(6), 2857-2888.

Drazen, Allen and Paul Masson. (1994) "Credibility of Policies Versus Credibility of Policymakers," Quarterly Journal of Economics 109(3), 735-754. 
Flood, Robert P., and Peter M. Garber. (1991) "The Linkage between Speculative Attacks and Target Zone Models of Exchange Rates," Quarterly Journal of Economics, 106, 136772.

Head, K. , Mayer, T., and J. Reis. (2010) "The Erosion of Colonial Trade Linkages after Independence," Journal of International Economics, 81(1): 1-14.

Head, K. and K. Reis. (2008) "FDI as an Outcome of the Market for Corporate Control: Theory and Evidence," Journal of International Economics, 74:2-20.

Hutchison, Michael and Ilan Noy. (2006) "Sudden Stops and the Mexican Wave: Currency Crises, Capital Flow Reversals and Output Loss in Emerging Markets," Journal of Development Economics, 79(1), 225-248.

Leaven, L. and F. Valencia. (2010) "Resolution of Banking Crises: The Good, the Bad, and the Ugly," IMF Working Paper 10/146.

Li, J., S. Kunrong, and R. Zhang. (2011) "Measuring Knowledge Spillovers: A Nonappropriable Returns Perspective," Working Paper, National Institute of Fiscal Studies, Tsinghua University.

Mendoza, E. (2010) Sudden Stops, Financial Crises, and Leverage. American Economic Review.

Noy, Ilan and Tam B. Vu. (2008) "Capital Account Liberalization and Foreign Direct Investment," North American Journal of Economics and Finance, 18(2), 175-194.

Obstfeld, M. (1994). "The Logic of Currency Crises," Cahiers Economiques et Monetaires 43: $189-213$.

Osei, Robert, Oliver Morrissey and Robert Lensink. (2002) "The Volatility of Capital Inflows: Measures and Trends for Developing Countries," CREDIT Research Paper, University of Nottingham.

Roodman, D. (2009) "A Note on the Theme of Too Many Instruments," Oxford Bulletin of Economics and Statistics, 71(1), 135-158.

Rose, Andrew. (2005) "One Reason Countries Pay Their Debts: Renegotiation and International Trade," Journal of Development Economics.

Rossi, S. and P. Volpin. (2004) "Cross-Country Determinants of Mergers and Acquisitions," Journal of the International Economics, Vol. 74(2): 277-304. 
Uhlig, Harald. (2010) "A Model of a Systemic Bank Run," Journal of Monetary Economics, 57(1), pp. 78-96.

Soliman, Mohamed, M. (2005) "The Effects of Currency Crises on Foreign Direct Investment Activity in Emerging Markets," Review of Applied Economics 1(2), 255-272.

UNCTAD. (2000) World Investment Report: 2000. United Nations Press.

UNCTAD (2011) World Investment Report: 2011. United Nations Press.

Wang, Miao and M. C. Sunny Wong. (2009) "What Drives Economic Growth? The Case of Cross-Border M\&A and Greenfield FDI Activities," Kyklos, 62(2), 316-330. 


\section{Appendix}

\section{Table A: List of developing and emerging economies by region}

South and East Asia (9)

China, India, Indonesia, Malaysia, Myanmar, Philippines, South Korea, Sri Lanka, Thailand

Middle East \& North Africa (4)

Algeria*, Egypt, Morocco, Tunisia

Sub-Saharan Africa (10)

Angola*, Central African Republic, Côte d'Ivoire, Ghana, Kenya, Mauritius, Nigeria*, South Africa,

Zambia, Zimbabwe

Latin America (18)

Argentina, Bolivia, Brazil, Chile, Colombia, Costa Rica, Dominican Republic, Ecuador*, El

Salvador, Guatemala, Honduras, Mexico, Nicaragua, Panama, Paraguay, Peru, Uruguay, Venezuela*

East Europe and Central Asia (4)

Poland, Romania, Russian Federation, Turkey

* OPEC member countries are excluded from the sample in our regressions.

\section{Table B: Typology of Crises}

\begin{tabular}{|c|c|c|}
\hline Name & Definition & Data Source \\
\hline Inflation crisis & An annual inflation rate of $20 \%$ or higher. & $\mathrm{R} \& \mathrm{R}$ \\
\hline Hyperinflation crisis & An annual inflation rate of $500 \%$ or higher & R\&R Chartbook \\
\hline Currency crash & $\begin{array}{l}\text { An annual depreciation versus the US dollar of 15\% } \\
\text { or more }\end{array}$ & $\mathrm{R} \& \mathrm{R}$ \\
\hline Banking crisis & $\begin{array}{l}\text { Defined by the following events: if there are no bank } \\
\text { runs, the closure, merging, takeover, or large-scale } \\
\text { government assistance of important financial } \\
\text { institution that marks the start of a string of similar } \\
\text { outcomes for other financial institutions }\end{array}$ & $\begin{array}{l}\text { R\&R } \\
\text { (Kaprio \& Klingebiel, Kaminsky \& } \\
\text { Reinhart, Jacome) }\end{array}$ \\
\hline $\begin{array}{l}\text { Systemic/severe } \\
\text { Banking crisis }\end{array}$ & $\begin{array}{l}\text { Defined by the following events: } \\
\text { Bank runs that lead to the closure, merging, or } \\
\text { takeover by the public sector of one or more } \\
\text { financial institutions }\end{array}$ & $\begin{array}{l}\text { R\&R } \\
\text { (Kaprio \& Klingebiel, Kaminsky \& } \\
\text { Reinhart, Jacome) }\end{array}$ \\
\hline External Debt crisis & $\begin{array}{l}\text { The failure of government to meet a principal or } \\
\text { interest payment on the due date (or within the } \\
\text { specified grace period). These episodes include } \\
\text { instances in which rescheduled debt is ultimately } \\
\text { extinguished in terms less favorable than the original } \\
\text { obligation }\end{array}$ & R\&R \\
\hline Domestic Debt crisis & $\begin{array}{l}\text { The above definition for external debt crisis applies. } \\
\text { In addition, domestic debt crises have involved the } \\
\text { freezing of bank deposits and/or forcible conversions } \\
\text { of such deposits from dollars to local currency }\end{array}$ & $R \& R$ \\
\hline Stock market crash & $\begin{array}{l}\text { A sudden decline of stock prices resulting in a } \\
\text { significant loss of paper wealth }\end{array}$ & $R \& R$ \\
\hline $\begin{array}{l}\text { Banking crisis } \\
\text { starting year }\end{array}$ & $\begin{array}{l}\text { The first year of the start of the systemic banking } \\
\text { crisis (defined by the above events) }\end{array}$ & R\&R Chartbook \\
\hline $\begin{array}{l}\text { External crisis } \\
\text { starting year }\end{array}$ & The first year of the start of the external debt crisis & R\&R Chartbook \\
\hline $\begin{array}{l}\text { Domestic crisis } \\
\text { starting year }\end{array}$ & The first year of the start of the external debt crisis & R\&R Chartbook \\
\hline
\end{tabular}


Table C: Data sources

\begin{tabular}{|c|c|c|}
\hline Variable & Definition & Source \\
\hline \multicolumn{3}{|l|}{ Dependent variables } \\
\hline FDI flows & Net FDI inflow (current \$US) & UNCTAD \\
\hline FDI stocks & FDI Sock (current \$̦US) & UNCTAD \\
\hline$M \& A$ & M\&A value (current \$US) & UNCTAD \\
\hline Greenfield FDI & $\begin{array}{l}\text { Constructed value of greenfield investment = Total } \\
\text { inflow - M\&A (current } \$ U S)\end{array}$ & $\begin{array}{l}\text { Authors calculations, } \\
\text { UNCTAD }\end{array}$ \\
\hline Vertical FDI & $\begin{array}{l}\text { Constructed value of vertical FDI = MNC sales in the } \\
\text { U.S. + MNC sales to other countries (current } \$ U S \text { ) }\end{array}$ & BEA \\
\hline Horizontal FDI & $\begin{array}{l}\text { Constructed value of horizontal FDI = MNC local } \\
\text { sales (current \$US) }\end{array}$ & BEA \\
\hline \multicolumn{3}{|l|}{ Control variables } \\
\hline GDP per capita & GDP per capita (current \$US) & WDI \\
\hline GDP growth & GDP growth (annual \%) & WDI \\
\hline Inflation & Inflation, consumer prices (annual \%) & WDI \\
\hline Exports & Exports of goods and services (current \$US) & WDI \\
\hline $\begin{array}{l}\text { Gross fixed capital } \\
\text { formation }\end{array}$ & Gross fixed capital formation (current \$US) & WDI \\
\hline Urban population & Urban population (\% total) & WDI \\
\hline Telephone lines & Telephone lines (per 100 people) & WDI \\
\hline $\begin{array}{l}\text { Mobile cellular } \\
\text { subscriptions }\end{array}$ & Mobile cellular subscriptions (per 100 people) & WDI \\
\hline Trade tax & Taxes on international trade (\% of revenue) & WDI \\
\hline Duties & Customs and other import duties (\% of tax revenue) & WDI \\
\hline Real GDP per capita & Real GDP per capita (constant price: Chain series) & Penn World Tables \\
\hline Real GDP & $\begin{array}{l}\text { Real GDP (population x real GDP per capita, Chain } \\
\text { series) }\end{array}$ & Penn World Tables \\
\hline Trade openness & Country openness (constant prices, in \%) & Penn World Tables \\
\hline Population & Population (in thousands) & Penn World Tables \\
\hline Education & Average education years & Barro and Lee \\
\hline $\begin{array}{l}\text { Squared education } \\
\text { difference }\end{array}$ & $\begin{array}{l}\text { Squared difference in average education years } \\
\text { between the host country and USA }\end{array}$ & $\begin{array}{l}\text { Authors calculations, } \\
\text { Barro and Lee }\end{array}$ \\
\hline Real per capita capital & $\begin{array}{l}\text { Real capital per capita (with varying depreciation } \\
\text { rate }=0,5,10,15 \% \text { ) }\end{array}$ & Jian Li, et al. (2011) \\
\hline \multicolumn{3}{|c|}{ Political and business environment } \\
\hline Political rights & Political rights index & Freedom House \\
\hline Civil liberties & Civil liberties index & Freedom House \\
\hline Political risk & Political risk rating & ICRG-PRS \\
\hline Quality of institutions & Quality of institution index & ICRG-PRS \\
\hline Government stability & Government stability index & ICRG-PRS \\
\hline $\begin{array}{l}\text { Socioeconomic } \\
\text { conditions }\end{array}$ & Socio-economic conditions index & ICRG-PRS \\
\hline Investment climate & Investment climate index & ICRG-PRS \\
\hline Corruption & Corruption index & ICRG-PRS \\
\hline
\end{tabular}




\begin{tabular}{|c|c|c|}
\hline \multicolumn{3}{|c|}{ Distance and other geographical, economic, and cultural variables } \\
\hline Land area & Land area (sq. km) & WDI \\
\hline Contiguous & $\begin{array}{l}\text { Dummy variable indicating HOST country and USA } \\
\text { are geographically contiguous }\end{array}$ & CEPII Gravity data set \\
\hline Weighted distance & $\begin{array}{l}\text { Population-weighted distance between the HOST } \\
\text { and USA }\end{array}$ & CEPII Gravity data set \\
\hline $\begin{array}{l}\text { Common official } \\
\text { language }\end{array}$ & $\begin{array}{l}\text { Dummy variable indicating Host country and USA } \\
\text { share a common official language }\end{array}$ & CEPII Gravity data set \\
\hline $\begin{array}{l}\text { Common ethnic } \\
\text { language }\end{array}$ & $\begin{array}{l}\text { Dummy variable indicating that Host country and } \\
\text { USA share a language which at least } 9 \% \text { of } \\
\text { population speak in each country }\end{array}$ & CEPII Gravity data set \\
\hline $\begin{array}{l}\text { Regional trade } \\
\text { agreement (RTA) }\end{array}$ & $\begin{array}{l}\text { Dummy variable indicating RTA between Host } \\
\text { country and USA }\end{array}$ & WTO \\
\hline WTO member & $\begin{array}{l}\text { Dummy variable indicating that Host country is a } \\
\text { member of WTO }\end{array}$ & CEPII Gravity data set \\
\hline
\end{tabular}


Table 1: FDI statistics (\$US millions at current prices and current exchange rates)

\begin{tabular}{|c|c|c|c|c|c|}
\hline FDI Inflows & Total & M\&A & Greenfield $^{1}$ & Horizontal & Vertical \\
\hline Totals: & $3,495,833.7$ & 698,676 & $2,656,992.4$ & $4,784,931$ & $2,350,113$ \\
\hline \multicolumn{6}{|l|}{ By decade } \\
\hline 1980s (1987-1989) & $51,431.8$ & $1,105.0$ & $24,101.2$ & 88,767 & 278,095 \\
\hline 1990s (1990-1999) & $911,317.1$ & $183,725.0$ & $680,480.1$ & $1,341,525$ & 588,552 \\
\hline 2000s (2000-2009) & $2,533,084.8$ & $513,846.0$ & $1,952,411.1$ & $3,354,639$ & $1,483,466$ \\
\hline \multicolumn{6}{|c|}{ By region (\# of countries in group): } \\
\hline South and East Asia (8) & $1,442,765.5$ & $219,481.0$ & $1,198,179.9$ & $1,337,290$ & 869,685 \\
\hline $\begin{array}{l}\text { Middle East and North } \\
\text { Africa (4) }\end{array}$ & $116,737.1$ & $36,336.0$ & $60,293.1$ & 30,254 & 9,951 \\
\hline Sub-Saharan Africa (10) & $212,899.1$ & $40,115.0$ & $115,741.5$ & 197,004 & 74,713 \\
\hline Latin America (18) & $1,150,643.2$ & $247,800.0$ & $866,846.1$ & $2,917,919$ & $1,281,832$ \\
\hline $\begin{array}{l}\text { East Europe and Central } \\
\text { Asia (4) }\end{array}$ & $572,788.7$ & $154,944.0$ & $415,931.8$ & 302,464 & 113,932 \\
\hline
\end{tabular}

${ }^{1}$ While Greenfield FDI = Total FDI inflows - M\&A value, following Calderon et al. (2004), we leave the values for Greenfield FDI missing where M\&A values are missing, consistent with Calderon, et al (2004). 
Table 2: Crises in developing and emerging countries, 1987-2009

\begin{tabular}{lr|rrr}
\hline Crisis Types & $\begin{array}{l}\text { Number of distinct } \\
\text { crisis episodes } \\
\text { (Total years in crisis) }\end{array}$ & \multicolumn{3}{c}{ By decade } \\
\cline { 2 - 5 } & 68 & 27 & 31 & $1987-1989$ \\
Banking crisis & $(255)$ & $(85)$ & $(131)$ & $(39)$ \\
Systemic banking crisis & 42 & 16 & 20 & 6 \\
& $(122)$ & $(45)$ & $(58)$ & $(19)$ \\
Currency crisis & 118 & 50 & 39 & 28 \\
& $(326)$ & $(152)$ & $(126)$ & $(47)$ \\
Inflation crisis & 54 & 21 & 24 & 9 \\
Hyperinflation crisis & $(315)$ & $(143)$ & $(133)$ & $(39)$ \\
& 10 & 6 & 3 & 1 \\
Stock Market crisis & $(27)$ & $(14)$ & $(9)$ & $(4)$ \\
Domestic debt crisis & 90 & 16 & 44 & 30 \\
& $(212)$ & $(63)$ & $(85)$ & $(64)$ \\
External debt crisis & 17 & 11 & 3 & 3 \\
& $(80)$ & $(39)$ & $(27)$ & $(13)$ \\
\end{tabular}

The sample excludes OPEC economies 
Table 3: Arellano-Bond Difference GMM Estimation for FDI flow

Dependent variable: FDI flow (in millions of real US dollars)

\begin{tabular}{|c|c|c|c|c|c|c|c|c|c|c|}
\hline $\begin{array}{l}\text { Independent } \\
\text { variable }\end{array}$ & (1) & 2) & (3) & (4) & (5) & (6) & (7) & (8) & $\begin{array}{l}\text { (9) } \\
\text { All crises }\end{array}$ & $\begin{array}{l}(10) \\
\text { Severe crises }\end{array}$ \\
\hline Banking crisis & $\begin{array}{l}-3,413.6^{* * *} \\
(753.3)\end{array}$ & & & & & & & & $\begin{array}{l}3,211.6^{* * *} \\
(742.6)\end{array}$ & \\
\hline $\begin{array}{l}\text { Systemic } \\
\text { banking crisis }\end{array}$ & & $\begin{array}{l}-1,377.6 \\
(901.1)\end{array}$ & & & & & & & & $\begin{array}{l}-1,219.3 \\
(909.5)\end{array}$ \\
\hline Inflation crisis & & & $\begin{array}{l}-2,891.8^{* * *} \\
(962.8)\end{array}$ & & & & & & $\begin{array}{l}-2,185.5^{* *} \\
(893.1)\end{array}$ & \\
\hline $\begin{array}{l}\text { Hyperinflation } \\
\text { crisis }\end{array}$ & & & & $\begin{array}{l}-19,737.4^{* * *} \\
(2,178.4)\end{array}$ & & & & & & $\begin{array}{l}- \\
19,690.2^{* * *} \\
(2,166.5)\end{array}$ \\
\hline Currency crisis & & & & & $\begin{array}{l}22.1 \\
(720.9)\end{array}$ & & & & $\begin{array}{l}40.9 \\
(704.7)\end{array}$ & \\
\hline $\begin{array}{l}\text { Stock market } \\
\text { crisis }\end{array}$ & & & & & & $\begin{array}{l}201.3 \\
(723.6)\end{array}$ & & & $\begin{array}{l}751.7 \\
(730.2)\end{array}$ & \\
\hline $\begin{array}{l}\text { Domestic debt } \\
\text { crisis }\end{array}$ & & & & & & & $\begin{array}{l}-1,930.1 \\
(1,422)\end{array}$ & & $\begin{array}{l}164.5 \\
(1,118.6)\end{array}$ & \\
\hline $\begin{array}{l}\text { External debt } \\
\text { crisis }\end{array}$ & & & & & & & & $\begin{array}{l}-5,496.4^{* * *} \\
(1,196.9)\end{array}$ & $\begin{array}{l}-4,832.7^{* * *} \\
(1,149.3)\end{array}$ & \\
\hline \# observations & 529 & 529 & 529 & 529 & 527 & 529 & 529 & 529 & 527 & 529 \\
\hline \# countries & 34 & 34 & 34 & 34 & 34 & 34 & 34 & 34 & 34 & 34 \\
\hline \# instruments & 164 & 164 & 164 & 154 & 164 & 164 & 164 & 164 & 244 & 170 \\
\hline
\end{tabular}

$*$ denotes $10 \%$ significance, $* * 5 \%$ significance, ${ }^{* * *} 1 \%$ significance

One-step standard errors in parentheses 
Table 4: Arellano-Bond Difference GMM Estimation for FDI stock

Dependent variable: FDI stock (in millions of real US dollars)

\begin{tabular}{|c|c|c|c|c|c|c|c|c|c|c|}
\hline $\begin{array}{l}\text { Independent } \\
\text { variable }\end{array}$ & (1) & (2) & (3) & (4) & (5) & (6) & (7) & (8) & $\begin{array}{l}\text { (9) } \\
\text { All crises }\end{array}$ & $\begin{array}{l}\text { (10) } \\
\text { Severe crises }\end{array}$ \\
\hline Banking crisis & $\begin{array}{l}-127,052.6^{* *} \\
(53,070.3)\end{array}$ & & & & & & & & $\begin{array}{l}-108,115.0^{* *} \\
(51,319.6)\end{array}$ & \\
\hline $\begin{array}{l}\text { Systemic } \\
\text { banking crisis }\end{array}$ & & $\begin{array}{l}-33,626.0 \\
(65,985.1)\end{array}$ & & & & & & & & $\begin{array}{l}-66.480 .5 \\
(64,634)\end{array}$ \\
\hline Inflation crisis & & & $\begin{array}{l}-136,041.7^{* *} \\
(65,981.6)\end{array}$ & & & & & & $\begin{array}{l}-93,265.6 \\
(60,785.6)\end{array}$ & \\
\hline $\begin{array}{l}\text { Hyperinflation } \\
\text { crisis }\end{array}$ & & & & $\begin{array}{l}-1,316,256^{* * *} \\
(172,400.2)\end{array}$ & & & & & & $\begin{array}{l}-1,284,376.0^{* * *} \\
(170,267.6)\end{array}$ \\
\hline Currency crisis & & & & & $\begin{array}{l}-46,434.4 \\
(49,158.7)\end{array}$ & & & & $\begin{array}{l}-30,524.3 \\
(47,965)\end{array}$ & \\
\hline $\begin{array}{l}\text { Stock market } \\
\text { crisis }\end{array}$ & & & & & & $\begin{array}{l}-44,888.9 \\
(49,801.9)\end{array}$ & & & $\begin{array}{l}44,795.6 \\
(49,709.2)\end{array}$ & \\
\hline $\begin{array}{l}\text { Domestic debt } \\
\text { crisis }\end{array}$ & & & & & & & $\begin{array}{l}-51,284.8 \\
(107,553.3)\end{array}$ & & $\begin{array}{l}21,423.5 \\
(105,997.1)\end{array}$ & \\
\hline $\begin{array}{l}\text { External debt } \\
\text { crisis }\end{array}$ & & & & & & & & $\begin{array}{l}-152,188.0^{*} \\
(82,783.7)\end{array}$ & $\begin{array}{l}-126,134.4 \\
(79,537.1)\end{array}$ & \\
\hline \# observations & 545 & 545 & 545 & 545 & 545 & 545 & 545 & 545 & 543 & 545 \\
\hline \# countries & 34 & 34 & 34 & 34 & 34 & 34 & 34 & 34 & 34 & 34 \\
\hline \# instruments & 182 & 182 & 182 & 182 & 182 & 182 & 182 & 182 & 267 & 189 \\
\hline
\end{tabular}

${ }^{*}$ denotes $10 \%$ significance, ${ }^{* *} \% \%$ significance, ${ }^{* * *} 1 \%$ significance.

One-step standard errors in parentheses 
Table 5: Arellano-Bond Difference GMM Estimation for Vertical FDI

Dependent variable: Vertical FDI (value of vertical FDI, in millions of real US dollars)

\begin{tabular}{|c|c|c|c|c|c|c|c|c|c|c|}
\hline $\begin{array}{l}\text { Independent } \\
\text { variable }\end{array}$ & (1) & $(2)$ & (3) & (4) & (5) & (6) & (7) & $(8)$ & $\begin{array}{l}\text { (9) } \\
\text { All crises }\end{array}$ & $\begin{array}{l}\text { (10) } \\
\text { Severe crises }\end{array}$ \\
\hline Banking crisis & $\begin{array}{l}-785.2 \\
(7,407.9)\end{array}$ & & & & & & & & $\begin{array}{l}3,866.7 \\
(6,897.8)\end{array}$ & \\
\hline $\begin{array}{l}\text { Systemic } \\
\text { banking crisis }\end{array}$ & & $\begin{array}{l}4,957.7 \\
(8,771.7)\end{array}$ & & & & & & & & $\begin{array}{l}7,543.148 \\
(8,537.0)\end{array}$ \\
\hline Inflation crisis & & & $\begin{array}{l}-29,829 * * * \\
(10,678.3)\end{array}$ & & & & & & $\begin{array}{l}-20,274.6^{* *} \\
(9,560.8)\end{array}$ & \\
\hline $\begin{array}{l}\text { Hyperinflation } \\
\text { crisis }\end{array}$ & & & & $\begin{array}{l}-299,297.6^{* * *} \\
(33,803.0)\end{array}$ & & & & & & $\begin{array}{l}-298,405.0^{* * *} \\
(33,642.7)\end{array}$ \\
\hline Currency crisis & & & & & $\begin{array}{l}4,993.0 \\
(7,369.8)\end{array}$ & & & & $\begin{array}{l}5,150.4 \\
(7,142.0)\end{array}$ & \\
\hline $\begin{array}{l}\text { Stock market } \\
\text { crisis }\end{array}$ & & & & & & $\begin{array}{l}976.0 \\
(6,475.7)\end{array}$ & & & $\begin{array}{l}-1,764.6 \\
(6,432.4)\end{array}$ & \\
\hline $\begin{array}{l}\text { Domestic debt } \\
\text { crisis }\end{array}$ & & & & & & & $\begin{array}{l}-2,345.0 \\
(14,807.9)\end{array}$ & & $\begin{array}{l}4,080.8 \\
(14,781.5)\end{array}$ & \\
\hline $\begin{array}{l}\text { External debt } \\
\text { crisis }\end{array}$ & & & & & & & & $\begin{array}{l}-32,961.4^{* * *} \\
(11,020.2)\end{array}$ & $\begin{array}{l}-22,597.1^{* *} \\
(10,433.5)\end{array}$ & \\
\hline \# observations & 282 & 282 & 282 & 282 & 282 & 280 & 282 & 282 & 282 & 282 \\
\hline \# countries & 21 & 21 & 21 & 21 & 21 & 21 & 21 & 21 & 21 & 21 \\
\hline \# instruments & 181 & 179 & 182 & 165 & 182 & 181 & 182 & 178 & 253 & 179 \\
\hline
\end{tabular}

${ }^{*}$ denotes $10 \%$ significance, ${ }^{* *} 5 \%$ significance, ${ }^{* * *} 1 \%$ significance.

One-step standard errors in parentheses 
Table 6: Arellano-Bond Difference GMM Estimation for Horizontal FDI

Dependent variable: Horizontal FDI (value of horizontal FDI, in millions of real US dollars)

\begin{tabular}{|c|c|c|c|c|c|c|c|c|c|c|}
\hline $\begin{array}{l}\text { Independent } \\
\text { variable }\end{array}$ & (1) & (2) & (3) & (4) & (5) & (6) & (7) & $(8)$ & $\begin{array}{l}\text { (9) } \\
\text { All crises }\end{array}$ & $\begin{array}{l}10) \\
\text { Severe crises }\end{array}$ \\
\hline Banking crisis & $\begin{array}{l}25,776.1 \\
(16,288.2)\end{array}$ & & & & & & & & $\begin{array}{l}22,515 \\
(15,435.2)\end{array}$ & \\
\hline $\begin{array}{l}\text { Systemic } \\
\text { banking crisis }\end{array}$ & & $\begin{array}{l}28,026.9 \\
(20,183.4)\end{array}$ & & & & & & & & $\begin{array}{l}34,567.3^{*} \\
(19,255.7)\end{array}$ \\
\hline Inflation crisis & & & $\begin{array}{l}-65,353.6^{* *} \\
(26,663.6)\end{array}$ & & & & & & $\begin{array}{l}-36,516.5 \\
(25,378.3)\end{array}$ & \\
\hline $\begin{array}{l}\text { Hyperinflation } \\
\text { crisis }\end{array}$ & & & & $\begin{array}{l}-580,530.8^{* * *} \\
(63,463.3)\end{array}$ & & & & & & $\begin{array}{l}-585,585.4^{* * *} \\
(62,537.9)\end{array}$ \\
\hline Currency crisis & & & & & $\begin{array}{l}-1,493.8 \\
(17,475.5)\end{array}$ & & & & $\begin{array}{l}-10,445.9 \\
(17,280.9)\end{array}$ & \\
\hline $\begin{array}{l}\text { Stock market } \\
\text { crisis }\end{array}$ & & & & & & $\begin{array}{l}18,591.9 \\
(14,435.3)\end{array}$ & & & $\begin{array}{l}8,767.9 \\
(14,465.9)\end{array}$ & \\
\hline $\begin{array}{l}\text { Domestic debt } \\
\text { crisis }\end{array}$ & & & & & & & $\begin{array}{l}3,902.4 \\
(38,364.3)\end{array}$ & & $\begin{array}{l}61,669.6 \\
(40,808.4)\end{array}$ & \\
\hline $\begin{array}{l}\text { External debt } \\
\text { crisis }\end{array}$ & & & & & & & & $\begin{array}{l}-82,672.5^{* * *} \\
(26,482.8)\end{array}$ & $\begin{array}{l}-73,236.8^{* * *} \\
(26,625.7)\end{array}$ & \\
\hline \# observations & 249 & 249 & 249 & 249 & 247 & 249 & 249 & 249 & 247 & 249 \\
\hline \# countries & 22 & 22 & 22 & 22 & 22 & 22 & 22 & 22 & 22 & 22 \\
\hline \# instruments & 179 & 176 & 179 & 163 & 177 & 178 & 172 & 177 & 233 & 177 \\
\hline
\end{tabular}

* denotes $10 \%$ significance, ${ }^{* *} 5 \%$ significance, ${ }^{* * *} 1 \%$ significance.

One-step standard errors in parentheses 
Table 7: Arellano-Bond Difference GMM Estimation for Mergers and Acquisitions (M\&A)

Dependent variable: M\&A Value (value of M\&A, in millions of real US dollars)

\begin{tabular}{|c|c|c|c|c|c|c|c|c|c|c|}
\hline $\begin{array}{l}\text { Independent } \\
\text { variable }\end{array}$ & (1) & (2) & (3) & (4) & (5) & (6) & (7) & (8) & $\begin{array}{l}\text { (9) } \\
\text { All crises }\end{array}$ & $\begin{array}{l}10) \\
\text { Severe crises }\end{array}$ \\
\hline Banking crisis & $\begin{array}{l}-1,361.4^{* *} \\
(569.9)\end{array}$ & & & & & & & & $\begin{array}{l}-951.0^{*} \\
(540.4)\end{array}$ & \\
\hline $\begin{array}{l}\text { Systemic } \\
\text { banking crisis }\end{array}$ & & $\begin{array}{l}-91.3 \\
(680.7)\end{array}$ & & & & & & & & $\begin{array}{l}-277.8 \\
(689.9)\end{array}$ \\
\hline Inflation crisis & & & $\begin{array}{l}-262.6 \\
(992.6)\end{array}$ & & & & & & $\begin{array}{l}-449.9 \\
(833.2)\end{array}$ & \\
\hline $\begin{array}{l}\text { Hyperinflation } \\
\text { crisis }\end{array}$ & & & & $\begin{array}{l}-2,132.5 \\
(1,784.0)\end{array}$ & & & & & & $\begin{array}{l}-2,372.4 \\
(1,794.0)\end{array}$ \\
\hline Currency crisis & & & & & $\begin{array}{l}-99.0 \\
(535.4)\end{array}$ & & & & $\begin{array}{l}91.4 \\
(524.6)\end{array}$ & \\
\hline $\begin{array}{l}\text { Stock market } \\
\text { crisis }\end{array}$ & & & & & & $\begin{array}{l}-360.9 \\
(472.9)\end{array}$ & & & $\begin{array}{l}-159.3 \\
(457.6)\end{array}$ & \\
\hline $\begin{array}{l}\text { Domestic debt } \\
\text { crisis }\end{array}$ & & & & & & & $\begin{array}{l}-2400.2^{* *} \\
(1,176.9)\end{array}$ & & $\begin{array}{l}-959.1 \\
(1,109.4)\end{array}$ & \\
\hline $\begin{array}{l}\text { External debt } \\
\text { crisis }\end{array}$ & & & & & & & & $\begin{array}{l}-1,619.4^{* *} \\
(821.9)\end{array}$ & $\begin{array}{l}-1,177.7 \\
(791.9)\end{array}$ & \\
\hline \# observations & 280 & 280 & 280 & 278 & 278 & 280 & 280 & 280 & 278 & 280 \\
\hline \# countries & 30 & 30 & 30 & 30 & 30 & 30 & 30 & 30 & 30 & 30 \\
\hline \# instruments & 162 & 160 & 154 & 164 & 164 & 161 & 156 & 164 & 221 & 166 \\
\hline
\end{tabular}

$*$ denotes $10 \%$ significance, $* * 5 \%$ significance, $* * * 1 \%$ significance.

One-step standard errors in parentheses 
Table 8: Arellano-Bond Difference GMM Estimation for Greenfield FDI

Dependent variable: Greenfield FDI Value (value of Greenfield FDI, in millions of real US dollars)

\begin{tabular}{|c|c|c|c|c|c|c|c|c|c|c|}
\hline $\begin{array}{l}\text { Independent } \\
\text { variable }\end{array}$ & (1) & (2) & (3) & (4) & (5) & (6) & (7) & (8) & $\begin{array}{l}\text { (9) } \\
\text { All crises }\end{array}$ & $\begin{array}{l}(10) \\
\text { Severe crises }\end{array}$ \\
\hline Banking crisis & $\begin{array}{l}816.7 \\
(601.1)\end{array}$ & & & & & & & & $\begin{array}{l}505.3 \\
(583.6)\end{array}$ & \\
\hline $\begin{array}{l}\text { Systemic } \\
\text { banking crisis }\end{array}$ & & $\begin{array}{l}163.5 \\
(745.4)\end{array}$ & & & & & & & & $\begin{array}{l}30.8 \\
(742.4)\end{array}$ \\
\hline Inflation crisis & & & $\begin{array}{l}-675.9 \\
(1,037.3)\end{array}$ & & & & & & $\begin{array}{l}-678.8 \\
(925.1)\end{array}$ & \\
\hline $\begin{array}{l}\text { Hyperinflation } \\
\text { crisis }\end{array}$ & & & & $\begin{array}{l}-2,904.0 \\
(1,867.4)\end{array}$ & & & & & & $\begin{array}{l}-2,871.2 \\
(1,869.9)\end{array}$ \\
\hline Currency crisis & & & & & $\begin{array}{l}852.6 \\
(592.2)\end{array}$ & & & & $\begin{array}{l}635.9 \\
(582.2)\end{array}$ & \\
\hline $\begin{array}{l}\text { Stock market } \\
\text { crisis }\end{array}$ & & & & & & $\begin{array}{l}541.6 \\
(531.7)\end{array}$ & & & $\begin{array}{l}346.7 \\
(504.1)\end{array}$ & \\
\hline $\begin{array}{l}\text { Domestic debt } \\
\text { crisis }\end{array}$ & & & & & & & $\begin{array}{l}1,106.6 \\
(1,198.9)\end{array}$ & & $\begin{array}{l}1,143.5 \\
(1,181.5)\end{array}$ & \\
\hline $\begin{array}{l}\text { External debt } \\
\text { crisis }\end{array}$ & & & & & & & & $\begin{array}{l}-581.6 \\
(925.7)\end{array}$ & $\begin{array}{l}-639.1 \\
(915.8)\end{array}$ & \\
\hline \# observations & 283 & 283 & 283 & 283 & 283 & 283 & 283 & 283 & 281 & 283 \\
\hline \# countries & 30 & 30 & 30 & 30 & 30 & 30 & 30 & 30 & 30 & 30 \\
\hline \# instruments & 162 & 160 & 164 & 154 & 164 & 161 & 161 & 164 & 223 & 166 \\
\hline
\end{tabular}

${ }^{*}$ denotes $10 \%$ significance, ${ }^{* *} 5 \%$ significance, ${ }^{* * *} 1 \%$ significance.

One-step standard errors in parentheses 